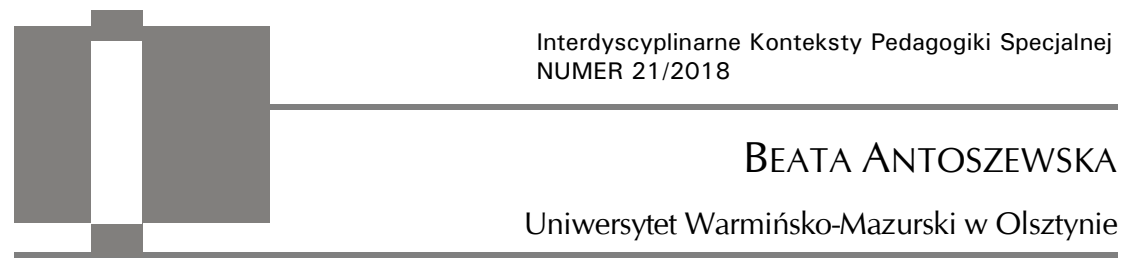

\title{
Obraz autointerpretacji profesji lekarskiej - narracje lekarzy
}

\begin{abstract}
Beata Antoszewska, Obraz autointerpretacji profesji lekarskiej - narracje lekarzy [Self-interpretation of the Medical Profession: Physicians' Narratives]. Interdyscyplinarne Konteksty Pedagogiki Specjalnej, nr 21, Poznań 2018. Pp. 279-302. Adam Mickiewicz University Press. ISSN 2300-391X. DOI: https://doi.org/ 10.14746/ikps.2018.21.15

This paper is an attempt to examine the senses and meanings attributed by physicians to the medical profession. The collected material is part of a larger project devoted to the physician-patient relationship reconstructed on the basis of individual narrations provided by physicians. The conducted research is closely linked to the qualitative perspective: Interpretative Paradigm and Interpretive Paradigm. The study was performed in the period 2015-2017. The examined group consisted of 16 subjects (6 female and 10 male physicians) from several provinces of Poland who were highly esteemed (subjective opinions) by their patients. The empirical data were collected by means of narrative interviews and the methodology applied for the analysis of the content was that of phenomenography.
\end{abstract}

KEY WORDS: doctor, physician - patient relationship 
Jesteśmy nie tym, czym jesteśmy, ale tym, co z siebie zrobimy¹.

\section{Wprowadzenie}

Lekarz to jedna z najstarszych profesji świata, z którą kojarzona jest szeroka wiedza i rozległe umiejętności służące choremu człowiekowi. Z perspektywy czasu można dostrzec, że różne były okresy profesji lekarskiej, jednak zainteresowanie zarówno nią, jak i osobą lekarza nie ustawało i nadal nie ustaje. Świadczą o tym prace zamieszczone w Historii medycyny pod red. Tadeusza Brzezińskiego², jak też Stulecie chirurgów czy Triumf chirurgów Jürgena Thorwalda ${ }^{3}$, w których opisywane są zarówno sukcesy, jak i porażki w odkrywaniu nowej wiedzy z zakresu medycyny. Jan Chryzostom nazywa lekarza iatros, czyli tak, jak nazywano po grecku człowieka leczącego ludzi, dbającego o chorego. Warto zauważyć, iż pisząc o osobie lekarza, J. Chryzostom przypisywał mu także inne określenia: „znakomici lekarze”, „biegli lekarze”, „mądrzy lekarze”, „bardzo doświadczeni lekarze”, "lekarze obchodzący się z pacjentem delikatnie", a zatem podkreślał nie tylko wiedzę medyczną ale i szerokie umiejętności. Warto zauważyć, o czym wspominał przywoływany Autor, że wśród lekarzy są tacy, którzy w nierównym stopniu opanowali sztukę lekarską i traktowanie pacjentów ${ }^{4}$.

Obecność lekarza zawsze była i zapewne pozostanie istotna dla każdego człowieka, w szczególności chorego ${ }^{5}$. Prawda ta dotyczy zarówno specjalistycznej wiedzy i umiejętności niezbędnych w sy-

1 A. Giddens, Nowoczesność i tożsamość, Wydawnictwo Naukowe PWN, Warszawa 2012, s. 107.

2 Zob. Historia medycyny, red. T. Brzeziński, Wydawnictwo PZWL, Warszawa 2000.

${ }^{3}$ Zob. J. Thorwald, Triumf chirurgów, Wydawnictwo Znak, Kraków 2010; idem, Stulecie chirurgów, Wydawnictwo Znak, Kraków 2009.

${ }^{4}$ W. Ceran, Jan Chryzostom o leczeniu i lekarzach, "Acta Universitatis Lodziensis", Folia Historica 1993, nr 48, s. 6-7.

${ }^{5}$ Poparciem tegoż twierdzenia są choćby Pamiętniki lekarzy, red. K. Bidakowski, T. Wójcik, Spółdzielnia Wydawnicza CZYTELNIK, Warszawa 1968. 
tuacji choroby, jak i umiejętności charakterystycznych dla troskliwego rodzica, który czyni wszystko by pomóc swojemu dziecku „reakcja przeniesieniowa"6.

Poszukując w literaturze wyjaśnień samego pojęcia „lekarz", nie odnajduje się ich wiele. Najczęściej oznaczają one fachowego pracownika służby zdrowia, mającego odpowiednie, wyższe wykształcenie, którego podstawowym zadaniem jest profilaktyka i leczenie ${ }^{7}$. Podkreśla się zatem, że pojęcie "lekarz" dotyczy wyłącznie tego, kto opanował wiedzę medyczną, sztukę lekarską . Ustawa o zawodzie lekarza Dz.U. z 2011 r. Nr 277, poz. 1634, art. 2 pkt 2 precyzuje, że wykonywanie zawodu lekarza polega na udzielaniu przez osobę uprawnioną (posiadającą wymagane kwalifikacje) świadczeń zdrowotnych: badanie stanu zdrowia, rozpoznawanie chorób i zapobieganie im, leczenie i rehabilitację chorych, udzielanie porad lekarskich, a także wydawanie opinii i orzeczeń lekarskich ${ }^{9}$. Sięgając jednak do opracowań związanych z biografiami znanych luminarzy medycyny lub opisujących pożądane cechy w profesji lekarskiej, wzbogaca się i dopełnia obraz osoby lekarza o niezbędne kompetencje miękkie. Lekarz - jak pisze Krzysztof Leśniewski ${ }^{10}$, odnosząc się do antycznej Grecji, był nie tylko znawcą chorób i sposobów ich leczenia, ale jednocześnie mędrcem i filozofem leczącym ciało i duszę.

W artykule podjęto próbę przedstawienia znaczeń, jakie medycy nadają pojęciu lekarz i profesji lekarskiej.

${ }^{6}$ Patrz: M.M. Hollender, Stosunki między lekarzem i pacjentem, [w:] Psychologia w praktyce lekarskiej, red. M.H. Hollender, PZWL, Warszawa 1975; A. Kępiński, Poznanie chorego, Wydawnictwo Literackie, Kraków 2002; J. Bogusz, Lekarz i jego chorzy, PZWL, Warszawa 1984.

7 P. Kostrzewski, J. Ziółkowski, red. Mała encyklopedia medycyny, Wydawnictwo Naukowe PWN, Warszawa 1999, s. 426.

8 W. Ceran, op. cit.

${ }^{9}$ Ustawa o zawodzie lekarza, Dz.U. z 2011 r., nr 277, poz. 1634, art. 2.2.

${ }^{10}$ K. Leśniewski, „Nie potrzebuja lekarza zdrowi..." Hezychastyczna metoda uzdrawiania człowieka, Wydawnictwo KUL, Lublin 2006. 


\section{Metodologia badań}

Zebrany materiał jest częścią szerszego projektu, który dotyczył relacji lekarz - pacjent zrekonstruowanej na podstawie indywidualnych narracji lekarzy. Badania prowadzono zgodnie z paradygmatem interpretatywnym (ang. Interpretative Paradigm)/interpretacyjnym (ang. Interpretive Paradigm) ${ }^{11}$. Ujmuje on człowieka jako aktora wciągniętego w świat swojego życia, tworzonego ze znaczeń negocjowanych $\mathrm{w}$ interakcjach społecznych ${ }^{12}$. Rzeczywistość zatem ma charakter procesualny i niejednoznaczny, a każdy ze współtworzących ją aktorów dąży do uczynienia jej rzeczywistością czytelną dla siebie. Istota zainteresowania badaczy paradygmatu interpretatywnego sprowadza się do wyjaśniania sposobu konstruowania świata w codziennych doświadczeniach podmiotów społecznych ${ }^{13}$.

Cel badań wiąże się z opisem relacji lekarz - pacjent, ukazaniem nadawanych przez lekarzy znaczeń profesji lekarskiej i samemu pojęciu „lekarz". Przedmiotem badań była relacja nawiązywana ${ }^{14}$ pomiędzy lekarzem a pacjentem, ściślej - znaczenia nadawane pojęciu „lekarz" i zawodowi lekarza.

Problem badawczy sformułowano następująco: Jak lekarze postrzegają swój zawód/profesję i jakie w związku z tym przypisują $\mathrm{mu} /$ jej znaczenia?

Badania prowadzono w latach 2015-2017. Dobór grupy był celowy, co oznacza, że badanymi była ściśle określona grupa lekarzy ciesząca się bardzo dobrymi opiniami (subiektywnymi) pacjen-

11 P. Chomczyński, Paradygmat interpretatywny, [w:] Stownik socjologii jakościowe, red. K. Konecki, P. Chomczyński, Difin, Warszawa 2012, s. 211.

12 D. Urbaniak-Zając, Jakościowa orientacja w badaniach pedagogicznych, [w:] Badania jakościowe w pedagogice, red. D. Urbaniak-Zając, E. Kos, Wydawnictwo Naukowe PWN, Warszawa 2013.

13 B. Sławecki, Znaczenie paradygmatów w badaniach jakościowych, Badania jakościowe. Podejścia i teorie, red. D. Jemielniak, Wydawnictwo Naukowe PWN, Warszawa 2012.

${ }^{14}$ Korzystano nie tylko z opinii zamieszonych na stronach internetowych, ale także ustnych - przekazywanych przez pacjentów. 
Tabela 1. Rozkład rozmówców pod względem stażu pracy i specjalizacji

\begin{tabular}{|l|c|l|}
\hline $\begin{array}{l}\text { Numer lekarza/ } \\
\text { /wywiadu/płeć }\end{array}$ & $\begin{array}{c}\text { Staż } \\
\text { pracy }\end{array}$ & \multicolumn{1}{|c|}{ Specjalizacja } \\
\hline I/1/M & 38 & pediatria II stopień \\
\hline II/2/K & 10 & stomatologia \\
\hline III/3/K & 45 & I i II stopień pediatrii \\
\hline IV/4/M & 34 & ginekologia położnictwa, endokrynologia ginekologiczna \\
\hline V/5/M & 19 & neurochirurgia \\
\hline VI/6/M & 23 & medycyna rodzinna \\
\hline VII/7/M & 23 & $\begin{array}{l}\text { chirurgia twarzowo-szczękowa, } \\
\text { medycyna paliatywna }\end{array}$ \\
\hline VIII/8/K & 30 & pediatria, onkologia dziecięca \\
\hline IX/9/M & 36 & ortopedia, II stopień chirurgii ortopedyczno-urazowa \\
\hline X/10/K & 26 & choroby wewnętrzne, nefrologia, transplantologia \\
\hline XI/11/K & 15 & choroby wewnętrzne, nefrologia \\
\hline XII/12/M & 8 & choroby wewnętrzne, choroby płuc \\
\hline XIII/13/M & 14 & urologia \\
\hline XIV/14/M & 18 & choroby wewnętrzne, medycyna sportowa i ratunkowa \\
\hline XV/15/K & 25 & chirurgia onkologiczna \\
\hline XVI/16/M & 14 & pediatria, gastroentereologia \\
\hline
\end{tabular}

tów ${ }^{15}$. Opinie dotyczyły zarówno wiedzy klinicznej (określano ich jako bardzo dobrych specjalistów) oraz umiejętności komunikacyjnych (bardzo mili, skoncentrowani na pacjencie, wyjaśniający wątpliwości). Medycy pochodzili z kilku województw, m.in. mazowieckiego, warmińsko-mazurskiego, podlaskiego i pomorskiego.

15 Interesowało mnie przede wszystkim badanie lekarzy, którzy są wysoko oceniani przez swoich pacjentów. Przyjąć można, że właśnie taki lekarz, jest osobą, z którą pacjenci chcieliby się kontaktować. Osobą, która sprosta stawianym wymaganiom i oczekiwaniom. Świadomie nie badałam lekarzy, którzy posiadali inne niż pozytywne (wysoko ocenione) relacje ze swoimi pacjentami. Chodziło przede wszystkim o spojrzenie na zawód lekarza i jego osobę przez pryzmat lekarzy mających bardzo dobre relacje ze swoimi pacjentami. 
Zarówno wiek badanych, jak i doświadczenie kliniczne były zróżnicowane. Najmłodszy badany miał 30 lat, najstarszy - 68. Charakterystykę grupy prezentuje tabela $\mathrm{nr} 1^{16}$. W trakcie analizy zamiennie stosuję wobec badanych określenia - rozmówcy, narratorzy.

Materiał badawczy zgromadzono za pomocą wywiadu narracyjnego. Metodą analizy zebranych treści była fenomenografia.

\section{Analiza wyników badań}

Wypowiedzi badanych lekarzy na temat rozumienia zawodu i osoby lekarza można podzielić na trzy kategorie:

1) metaforyczną (gdzie następuje porównanie zawodu lekarza do innych zawodów),

2) społeczną (nawiązującą do perspektywy społecznej),

3) codzienną (nawiązującą do wymagań codzienności)

Poniżej dokonano opisu każdej z wymienionych kategorii.

\section{Metaforyczna}

Wiąże się ona z porównywaniem osoby lekarza i uprawianej przez niego profesji do innych zawodów czy relacji społecznych/rodzinnych, ukazując jednak jej wyjątkowość.

[...] to jest to, ciagłe obcowanie z materiatem biologicznym ludzkim na poziomie duchowym, emocjonalnym, intelektualnym. To jest wyjatkowe, absolutnie $(\mathrm{X} / 10 / \mathrm{K})$

Warto zasygnalizować, że opisywana kategoria jest najliczniejsza (odnaleźć ją można niemalże u wszystkich badanych) i nie jest wyłącznie charakterystyczna dla myślenia samych narratorów. Często bowiem pacjenci, określając lekarzy, posługują się tego rodzaju konceptualizacjami, których treść jest dość rozległa sięga bowiem

16 Prezentacja danych w tabeli odzwierciedla kolejność prowadzonych wywiadów. 
tych związanych z nadludzkimi cechami, posiadaniem nadprzyrodzonych sił, zdolnych przywrócić zdrowie pacjenta, uchronić go od śmierci czy odroczyć jej moment aż po te związane z postrzeganiem lekarza jako bliźniego czy brata.

Pierwszą, często powtarzającą się, metaforą jest ta, w której lekarz przyrównywany jest do boga. Może ona mieć swe źródło w przysiędze składanej przez lekarzy, poprzez którą nawiązywali oni relację przymierza z bogami, zakorzeniając tym samym swój moralny autorytet w sferze sacrum. Asygnowało ono mocno powinność medyka, który stawał się pomocnikiem bogów i bogiń w przywracaniu i utrzymywaniu zdrowia. Było to zadanie należne bogom ${ }^{17}$. Lekarz określany jest jako ktoś wyjątkowy, obdarzony mocą uzdrawiania i ratowania. To ktoś, kto posiada w rękach wiedzę, umiejętności i narzędzia przywracające sprawność, czy zdrowie. Konceptualizacja boga wskazuje na moc twórczo-sprawczą ${ }^{18}$, a lekarz urasta tu do rangi świętego. Jednak napotyka na ograniczenie. W narracjach nie ma mowy o innych boskich przymiotach, tj.: dobrotliwość, łaskawość, miłosierdzie. Najbardziej uwidoczniona została ona $\mathrm{w}$ narracjach trzech lekarzy (neurochirurga, transplantologa czy lekarza SOR-u), którzy często doświadczają śmierci pacjentów, pomimo podejmowanych czynności, ale również ratują pacjentów przed śmiercią. Oto przykłady takich ujęć:

17 Zob. K. Szewczyk, Bioetyka. Medycyna na granicach życia, Wydawnictwo Naukowe PWN, Warszawa 2009. O religijnych korzeniach medycyny wspominają także Anselm Grun oraz Meinard Dufner, pisząc, iż lekarze antyczni wierzyli, że cała moc uzdrawiania pochodziła od boga. Zdrowy tryb życia należało jeszcze powiązać z oddawaniem czci bogom, właściwy stosunek do stwórcy świata. Zob. Ta choroba zmierza ku życiu, Wydawnictwo Salwador, Kraków 2008.

${ }^{18}$ W. Szumowski uzdrowicielem nazywa każdego, kto ma moc, umiejętność czy dar uzdrawiania chorych. Do tej grupy zalicza przede wszystkim lekarzy. Pierwotnie uzdrawiał każdy, kto tylko umiał i chciał to czynić: znachor, czarodziej, baba, kapłan, wódz; później zawodowy lekarz, w świątyniach znowu kapłan, potem Chrystus, święci. Wszystkie wymienione osoby były uzdrowicielami. Świadectwo w zakresie wykonywania praktyki lekarskiej wymagane było w wiekach średnich u Arabów, w szkole salernitańskiej, zwłaszcza od czasu sławnych konstytucji cesarza Fryderyka II. Szerzej zob. W. Szumowski, Filozofia medycyny, Wydawnictwo Marek Derewiecki, Kęty 2005, s. 113-114. 
[...] prawda jest taka, że lekarz jest bogiem w tym kraju, naprawdę. Mimo że wszyscy staraja się z tej estymy zawód odrzeć... Jest to osoba, od której często zależy nasze życie. I tak naprawdę my możemy bardzo dużo. Możemy komuś skrócić cierpienie, w sensie usunać je lub zmniejszyć. Jeśli jesteśmy przeszkoleni odpowiednio możemy wyprowadzić go z choroby, żeby uniknąt kalectwa. [...] jeżeli lekarz jest kompetentny i potrafi to zrobić, to super. Tak powinno być (XIV/14/K)

Powiem tak: w mojej specjalności ta wyjątkowość polega na tym, że rzeczywiście człowiek czasami ma w swoich rękach... ma to, że decyduje o tym, czy dany pacjent przeżyje. Nawet to. Czy będzie sprawny? Czy będzie mówit? Czy będzie np. Sparaliżowany, czy nie? To jest jakby w moich rękach często $(\mathrm{V} / 5 / \mathrm{M})$.

[...] komunikować się z ludźmi w pewnych obszarach, które dla innych sa niedostęne, jak gdyby się było panem życia $i$ śmierci. Bo tak jest. Usypia się człowieka na stole. Staje chirurg $i$ wszystko w jego rękach. Albo ma złote ręce, albo jest partaczem. I albo przewiezie człowieka w te strone, albo niestety w te stronę. No to, to sa te wyjatkowości. To jest codzienne obcowanie na granicy życia i śmierci (X/10/M).

Powodem powyższych interpretacji jest zapewne (także) coraz częściej właściwe pacjentom pragnienie życia w ciągłym zdrowiu, niwelowania bólu za wszelką cenę czy unikania cierpienia i śmierci. Rodzi się złudna nadzieja na możliwość odsunięcia jej, szczęśliwego życia czy długowieczności. Wiele osób niekiedy oczekuje od lekarzy, a zatem także od medycyny, rzeczy niemożliwych do osiągnięcia, postrzegając ich jako nowych kapłanów współczesności oraz królów mających władzę życia i śmierci, a także proroków ostatecznego losu człowieka ${ }^{19}$. Z kolei sami lekarze - mówiąc o szczególnych wyzwaniach, z jakimi na co dzień się mierzą - przede wszystkim wskazują na wiedzę i umiejętności niezbędne w zawodzie, by ratować życie pacjentów. Nikt, kto nie jest lekarzem (nie studiuje medycyny, nie posiada przygotowania medycznego), nie może wykonywać zarezerwowanych dla lekarzy czynności, nie ponosi takiej odpowiedzialności. Niekiedy - jak wskazują narracje - rodzi się

19 Zob. K. Leśniewski, "Nie potrzebują..." . 
pokusa myślenia o sobie jako bogu, zwłaszcza gdy zostanie osiągnięty sukces terapeutyczny, mimo niewielkich szans na powodzenie.

Innym zagadnieniem jest system kształcenia studentów medycyny, który zakłada wszechwiedzę i nieomylność, wtłacza takie myślenie. Osoba, która wkracza w tak konstruowany obraz swego zawodu, staje się kimś innym, ma niejako zaburzoną percepcję swoich możliwości, nie dostrzega ograniczeń, a tym samym nie dopuszcza porażki. Czasem nie wynika ona z błędu, ale tkwi w możliwościach biologicznych organizmu konkretnego pacjenta. Tego rodzaju myślenie utrudnia funkcjonowanie w zawodzie, stając się źródłem stresu i nieustannych dylematów oraz odpowiedzialności.

[...] w trudnych $i$ beznadziejnych przypadkach dalej robiłam wszystko, tak jakbym chciała odwrócić dzieje losu. I to było zbędne. Znaczy okropne. Teraz, jak już nabratam rozumu troszke innego, zawodowego..., to sobie zdaje sprawe, co on wtedy chciat opisać. Człowiek byt tak naładowany i wydawało mu się, że każda godzina, każdy dzień ma znaczenie, nie patrzac na jakość, co się dzieje (III/3/K)

[...] medycyna wymaga, żeby oni byli wszechwiedzacy, żeby oni wszystko wiedzieli, żeby oni wiedzieli, co maja zrobić. Wymaga się od lekarzy, żeby byli nadludźmi w pewnym sensie. On nie może się mylić. Nie może, bo jak on się myli, to jest ztym lekarzem. A kto chciałby być złym lekarzem? Więc nie wpisują w swój zawód czegoś takiego, że w moim zawodzie, ja się będę mylit. Oni wpisuja coś takiego: "Ja nie będę się mylit". Fajnie by było się nie mylić, bo to pacjentom byłoby dobrze, bo wtedy nie byłoby żadnych szkód. Ale szkody będa, bo ja się zawsze będę mylit. [...] Więc jeśli medycyna, społeczeństwo, pacjenci oczekuja tego, że lekarz będzie znat odpowiedź na wszystkie pytania, będzie zawsze wiedziat co ma zrobić itd., to oni sie jakoś do tego dostosowuja, tzn. chca rzeczywiście odpowiedzieć na takie zapotrzebowanie. Czyli jak ode mnie czegoś oczekuja, to ja to zrobię. To znaczy, ja musze wiedzieć zawsze, ja musze wiedzieć szybko, ja muszę wiedzieć na pewno, a bardzo często tak nie jest. [...] Po prostu takim człowiekiem, któremu się wydaje, że on wie, że on wie zawsze, $\dot{z} e$ on wie wszystko, że on wie lepiej, że nie musi stuchać pacjentów, nie musi $z$ nimi rozmawiać (VI/6/M).

Konceptualizacja lekarza - boga może mieć swoje konsekwencje w relacji z pacjentem i prowadzić do hierarchicznego układu lekarz 
- pacjent oraz przedmiotowego traktowania pacjenta. Jest swego rodzaju pułapką prowadzącą do tworzenia utopijnego obrazu funkcjonowania lekarza w zawodzie, wywyższania się, przypisywania sobie wyższej pozycji w hierarchii społecznej (zarówno wśród innych ludzi, jak i zawodów). Konieczna jest zatem w każdym przypadku refleksja, pokora i realna ocena rzeczywistości (sytuacji medycznej oraz swoich możliwości).

Z narracji wynika, że system kształcenia medyków to nie jedyne źródło omawianej konceptualizacji. Równie istotne jest społeczeństwo oczekujące od lekarza nieomylności i niemalże wszechwiedzy. Każdy pacjent ceni sobie lekarza, który nie popełnia błędów i jest pewny podejmowanych decyzji. Lekarz jest bogiem do momentu, w którym popełni błąd ${ }^{20}$.

[...] tylko jeszcze jedno powiem, że pacjentowi się wydaje, że doktor ma być zawsze uśmiechnięty i nie ma prawa być chory. I nie ma prawa mieć swoich problemów. Jest to u nas prawie powszechne. "Co, pan doktor chory?" Albo pamiętam z młodości. Siedzimy na odprawie. Wchodzi pacjent [pyta: - B.A.] jest Doktor X? Nie ma [odpowiadam - B.A.], chory. "Jak to chory, jak to chory?" [zdziwiony pacjent - B.A.]. Jeszcze w naszym społeczeństwie pokutuje, że ten doktor wiecznie ma być zdrowy i zadowolony. On nie ma prawa się rozwieść, on nie ma prawa mieć kłopotów, chorego dziecka czy nieprzespanej nocy (IX/9/M).

Omawiana metafora, mimo że utrudnia funkcjonowanie $\mathrm{w}$ roli lekarza, jednak jest źródłem społecznego prestiżu i przywileju. „To obciążenie, ale też taki przywilej w pewnym stopniu" (V/5/M). Warto zwrócić uwagę, że metafora boga nie tylko dotyczy działań podejmowanych wobec pacjenta, ale także zajmowanej przez lekarza pozycji społecznej. Ukształtowana jest ona poprzez wiedzę i umiejętności medyczne lekarza. W perspektywie społecznej posia-

20 Oczekiwania wobec lekarza są wygórowane i wiążą się z tym, iż jego działania będą miały charakter cudu. Jedynie lekarzowi stawia się żądania i życzenia z natury rzeczy niewykonalne, tak jakby posiadał on nieograniczoną wiedzę nad chorobami i śmiercią - zauważał Stefan Schwarz, zob. S. Schwarz, O zawodzie lekarza, „Przegląd lekarski” 1973, nr 5, s. 418. 
danie lekarza $\mathrm{w}$ rodzinie lub $\mathrm{w}$ gronie znajomych pomaga $\mathrm{w}$ załatwieniu spraw związanych ze zdrowiem (np. postawienie diagnozy, odesłanie do odpowiedniego specjalisty), a zatem daje poczucie bezpieczeństwa i spokoju. Warto zauważyć, że przekonanie owo funkcjonuje powszechnie i często jest przejmowane od innych ${ }^{21}$.

[...] Moja mama, jak się rozwodzitam, powiedziała: „Ty jesteś lekarzem. Ty zawsze jesteś wygrana". Powiedziałam, że to nie jest tak. Nie zgadzam sie $z$ nią. Po jakimś czasie jednak odczułam, że miała rację... I to mówię nie ze złośliwością czy satysfakcja, tylko raczej z przykrościa (XIV/14/K).

Podobną do powyżej wskazanej jest metafora szamana ${ }^{22}$. Pojawia się w jednej narracji, jednak warto ją zaakcentować. Szaman jest prezentowany jako wybraniec, "ssprowadzający” zdrowie, a wyrzucający chorobę. Podkreślana jest również sytuacja dysponowania wieloma wartościami, z których najważniejsze są życie i zdrowie.

[...] to jest taki trochę zawód szamana, który polega na tym, że ma się w ręku wiele wartości, które innym nie sa dane. Walka z choroba, jest często na pograniczu często życia i śmierci (X/10/K).

Kolejną metaforą jest kapłan (spowiednik), czyli osoba, której można zwierzyć się ze swoich tajemnic, bowiem pod żadnym pozorem ich nie wyjawi ${ }^{23}$. Jak twierdzi Roman Tokarczyk ${ }^{24}$, konceptualizacja kapłana ma uniwersalny i ponadczasowy zasięg - „tak jak

${ }^{21}$ Peter L. Berger przekonuje, że tożsamości są nadawane społecznie. Muszą one być także społecznie w sposób regularny potwierdzane. Stajemy się tacy, za jakich inni nas uważają, zob. P.L. Berger, Zaproszenie do socjologii, Wydawnictwo Naukowe PWN, Warszawa 1988, s. 97.

${ }^{22}$ Szamani pośredniczyli pomiędzy człowiekiem a siłami nadprzyrodzonymi $\mathrm{w}$ różnych sprawach, często $\mathrm{w}$ sprawach zdrowia. Szamanów można traktować jako pierwszych profesjonalnych lekarzy, zob. T. Brzeziński, Wprowadzenie, [w:] Historia medycyny, red. T. Brzeziński, PZWL, Warszawa 2000, s. 26.

${ }_{23}$ Pacjent powinien poufnie przekazać lekarzowi wszystkie informacje, by mógł on postawić właściwą diagnozę i zaplanować leczenie.

${ }^{24} \mathrm{R}$. Tokarczyk, Normatywne aspekty relacji lekarz - pacjent, [w:] Humanizm i medycyna. Relacje lekarz-pacjent, red. K. Imieliński, Warszawa 1993, s. 92. 
kapłanem ludzkiej duszy jest duchowny, tak kapłanem ludzkiego ciała pozostaje lekarz"25. Wydaje się jednak, że omawiana konceptualizacja dotyczy bardziej problemów chorego, które nie są bezpośrednio związane z wymiarem somatycznym, ale z psychiką pacjenta.

[...] I człowiek też jest takim trochę powiernikiem czasami. [...] osoba, która ma wystuchać niż zalecić dawkę czy coś (XVI/16/M).

Lekarz ma być po prostu osoba pomocna [...] jest też kimś w danym momencie bliskim. [...] Ta matka mu powie wszystko. Potrafi powiedzieć rzeczy, które nie każdemu była w stanie powiedzieć. Ona potrafi powiedzieć o swoich problemach w rodzinie. Nawet o swoich własnych problemach (III/3/K).

[...] to jest zawód, w którym pacjenci powierzaja nam pewne swoje tajemnice, że wiemy o pewnych rzeczach, że nadużycie ich może spowodować, że będziemy cholernie bogaci, zamożni. Bóg wie, co jeszcze, ale sprzeniewierzymy sie zawodowi (VII/7/M).

[...] lekarzowi czasami ludzie mówią różne rzeczy, których nie można później powtórzyć. Czasami lekarz wie więcej... Ja sobie czasami żartuje, mówiac: "Proszę mi opowiedzieć wszystko od początku, bo lekarzowi trzeba powiedzieć więcej niż księdzu na spowiedzi i prokuratorowi". Wielokrotnie się o tym przekonałem. Takie w życiu różne sytuacje byty, że włosy się jeżą (IX/9/M).

[...] Opowiada nam się o rzeczach, o których zwykle się nie opowiada w szerszym kregu. Nie rozbieramy sie na przykład przed obcymi ludźmi. [...] Wyjątkowość tego zawodu polega na tym, że w sposób naturalny sa przekraczane granice, które w innych relacjach międzyludzkich nie sa przekraczane. Nawet $w$ sklepie przebieramy się w przebieralni. A tu wchodzimy do człowieka, którego pierwszy raz na oczy widzimy $i$ się przed nim rozbieramy. Ta wyjątkowość jakby polega na tym, że pewne naturalny opór i granice musza być przetamane, żebyśmy mogli dobrze wykonywać nasz zawód [...] Z racji tego zawodu doświadczamy pewnych praw, których normalnie inni nie maja i powinniśmy to szanować (XI/11/K).

Powyższa metafora (kapłana) wskazuje silnie utrwalone w naszej kulturze przekonanie, że w relacji lekarz - pacjent zostają znie-

25 Ibidem. 
sione niektóre z obowiązujących norm społecznego funkcjonowania, np. te wyrażające się $\mathrm{w}$ zachowywaniu intymności i pewnego dystansu. W relacji medycznej lekarz - pacjent nawiązywany jest niesymetryczny kontakt polegający nie tylko na nierówności wiedzy i władzy, ale także na ujawnianiu przez pacjenta osobistych, intymnych i skrywanych problemów. Problemy te ujawnia pacjent, natomiast lekarz dokonuje koniecznego oglądu i czasem wysłuchuje pacjenta, jednak on sam nie odsłania żadnej ze swoich słabości, dylematów, kłopotów lub tajemnic. Z narracji wynika, że można to ujęcie traktować w kategoriach problemu. Taka perspektywa charakteryzuje pacjenta. Można też dostrzegać w tym wyjątkowość. To jest perspektywa lekarza. Obie perspektywy są słuszne jednak nie należy pomijać optyki pacjenta i uznawać jej za mniej istotną, „normalną kolej rzeczy" służącą diagnozie. Należy dbać o to, by sytuacje związane z wykonywaniem badań, sytuacje diagnostyczne, hospitalizacje były jak najmniej wstydliwe i bezosobowe dla pacjenta.

Kolejne rozumienie pojęcia „lekarz” można powiązać z symbolicznym bratem. Lekarz postrzegany jest jako brat, a relacja jest porównana do relacji braterskiej ${ }^{26}$. Relacje pomiędzy braćmi w społecznościach plemiennych stanowią odmianę tzw. relacji pokrewieństwa, czyli tej, która istnieje już w momencie narodzin z racji więzi pochodzenia ${ }^{27}$. Innym istotnym rodzajem jest tworzenie więzi braterskich między niepowiązanymi biologicznie jednostkami, które chcą stać się „niczym bracia”. Pierwotne źródło tych więzi osadzone jest w wierzeniach religijnych lub magicznych ${ }^{28}$. Obowiązki braterskie są wzajemne „kiedy jeden z partnerów robi dla drugiego coś wartościowego, od tego drugiego oczekuje się, że prędzej czy

${ }^{26}$ Można być bratem jedynie w czymś. Jeżeli braknie łączącego więzła, ludzie będą po prostu żyli jeden obok drugiego, ale nie będą powiązani między sobą. Nie można być bratem w oderwaniu", zob. A. de Saint-Exupery, Nocny lot. Ziemia planeta ludzi. Pilot wojenny, Biblioteka Klasyki Polskiej i Obcej Wydawnictwo Literackie, Kraków 1974, s. 339.

${ }^{27}$ F. Znaniecki, Relacje społeczne i role społeczne, Wydawnictwo Naukowe PWN, Warszawa 2011.

28 Ibidem, s. 183 i n. 
później również zrobi coś wartościowego dla swojego partnera”29. Nie oznacza to, że obowiązki muszą być jednakowe „zależy to od tego, jak bardzo każdy z nich potrzebuje pomocy drugiego, a także od tego, ile każdy może faktycznie zrobić na rzecz drugiego" 30.

[...] Ten szpital byt zawsze bardzo rodzinny, czyli jeżeli ktoś stawat i mówit: "Stuchaj mam kłopot", to w tym szpitalu zawsze mógt liczyć na pomoc i nawet jeśli ludzie pracowali gdzie indziej, to tam zawsze docierali. [...] Ale dla mnie chore dziecko woźnego czy profesora jest takim samym chorym dzieckiem. Tu kryterium jest ciężkość choroby, a nie profesja czy zależność i w jakimś sensie udało mi się do tej pory utrzymać. [...] Pamiętam takiego chłopca [...] przyszedt z domu dziecka. Byt bezmózgowcem. Miat ciężkie zapalenie ptuc i na moim dyżurze umierat. Wszyscy jakby uciekali od tej sprawy. Powiedziatem pielegniarkom, że moga się nie martwić, ja biore to na siebie. Ale "biorę na siebie” oznaczało, że ja wiem co trzeba zrobić. Ja byłem już po onkologii i po opiece paliatywnej. [...] Świadomość odchodzenia i trzymania takiego dzieciaka za rękę. Patrzenie na monitor, kiedy on w ogóle wygasza się. To bardziej jako obecność, bo zrobić tam niewiele można byto, ale ta historia miata dalszy ciąg. Przyszedt następnego dnia człowiek, który się przedstawit, że jest ojcem tego chtopca i zacząt mi płakać, mówiąc: "Mi powiedziano, że z niego nic nie będzie, to ja sie go zrzekłem i byt w domu dziecka". I teraz ja mogłem powiedzieć: "Źle zrobiłeś". Nie, pomyślatem sobie, że ta chwila jest dla niego chwila na życie. Powiedziatem: "Niech się pan nie przejmuje, ja pana zastapiłem, trzymajac tego chłopca za rękę. I nikt by tego lepiej nie zrobit. Mógł być pan pewny, że miat ojca przy sobie". Dałem mu szansę na życie, że on źle postapit, ale ktoś to naprawit $(\mathrm{I} / 1 / \mathrm{M})$.

W narracjach znalazło się też porównanie pracy i osoby lekarza z fryzjerem, wróżką czy psychologiem. Podobieństwo dotyczy uwypuklenia znaczenia rozmów w wymienionych zawodach. Na pozór są one odmienne, jednak analizując kontekst, w jakim się pojawiają, dostrzega się podobieństwo i dopełnienie. Lekarz jawi się jako osoba, która odmieni los pacjenta na lepszy, a ściślej bardziej dla niego korzystny. Lekarz ma zatem „bajkową moc” zdolną

${ }^{29}$ Ibidem, s. 186.

30 Ibidem. 
zmienić życie pacjenta. Z kolei porównanie do fryzjera wskazuje na zmianę, która dotyczy bezpośrednio organizmu pacjenta. Lekarz podobnie, jak fryzjer ma być zręczny technicznie, a podjęte działania mają odmienić zarówno wygląd, jak i samopoczucie pacjenta. Jednak by, dokonana zmiana usatysfakcjonowała pacjenta należy poznać jego potrzeby i pragnienia, co uczynić może tylko przyjaciółka lub psycholog. Przywołanie psychologa nie jest zapewne przypadkowe, bowiem nawiązuje do wcześniejszych wypowiedzi o zaspakajaniu potrzeb pacjenta nie tylko medycznych, ale także tych związanych ze sferą psychiczno-duchowo-społeczną. Warto zaznaczyć, że wszystkie określenia pojawiają się w kontekście dość charakterystycznym dla uprawianej przez narratora specjalizacji stomatologii. W tym przypadku staje się bardziej zrozumiałe „odmienienie" pacjenta zwłaszcza zewnętrznie.

Ostatnie porównanie to urzędnik. Mowa tu o czysto usługowej wymianie odbywającej się pomiędzy zainteresowanymi. Lekarz zajmuje stanowisko urzędnika i zobowiązany jest do wykonywania czynności należących do jego obowiązków. Zwykle pozycja urzędnika wiązała się z obdarowaniem szacunkiem i prestiżem, jednak nie aktualnie - choć zależy to od środowisk. Lekarze, jak wynika z narracji, dość często wskazują na tego typu postawy pacjentów, którzy postrzegają lekarza wyłącznie przez pryzmat świadczenia usług (np. wypisywanie zaświadczeń, recept czy innych dokumentów). Potwierdza tę sytuację przewodniczący Komisji Etyki DRL ${ }^{31}$ mówiąc, że lekarz w kontekście „usług/procedur medycznych”, „algorytmów postępowania" staje się usługodawcą. Zatem duża część pacjentów nie tylko przychodzi do lekarza z oczekiwaniem „wykonania usługi”, ale również próbuje rozliczać go z jej wykonywania. Jednak proces leczenia - jak określa słusznie Autor - jest czymś więcej niż tylko usługą.

[...] Na pewno ta grupa zawodowa straciła pewna dozę szacunku u pacjentów. Często jesteśmy traktowani trochę tak jak urzędnicy. Pacjenci chca od nas czegoś mamy im to dać, tak po prostu na zasadzie petenta. Sami wchodza w role

${ }^{31}$ M. Orlicz-Benedycka, Dehumanizacja medycyny zagraża lekarzom $i$ pacjentom, „Medium” 12/2012-1/2015. 
petenta, a nas traktuja jak urzędnika. [...] nie jest to dobra rola pacjenta jako petenta lekarza jako urzędnika (XV/15/K).

[...] Kontaktuję się z lekarzem, rodzinnym, a on do mnie mówi: „Panie doktorze, z lista badań, które mam zrobić oni przyszli do mnie po wypisaniu pacjenta z nieuleczalnym nowotworem. Badań na chorobe tarczycy, badań na chorobe prostaty. Prawdopodobnie szukali w Internecie, nie mając pojęcia o tym wszystkim. Powiedzieli, że ja jestem od wypisywania [...]. Co mam zrobić?" A ja widzę, że to absurdalne i niepotrzebne (VII/7/M).

[...] Jest coraz więcej papierków, wiecznie siedzimy w komputerach. Liczymy punkty. Robimy coś, czym tak naprawdę wedtug mnie powinien zajmować się ktoś inny. [...] Ale to mnie martwi (XVI/16/M).

\section{Społeczna}

Druga z głównych kategorii wiąże się z perspektywą społeczną zawodu, w której odsłaniane są wzniosłe idee. Konceptualizacje podkreślają zaufanie publiczne ${ }^{32}$, odpowiedzialność za życie i zdrowie pacjentów. W tym kontekście warto zauważyć, że pracę lekarza reguluje wiele przepisów ustawa o zawodach lekarza i dentysty, ustawa o izbach lekarskich oraz ustawą o zakładach opieki zdrowotnej ${ }^{33}$. Z kolei zasady etyczne, które powinny kierować pracą lekarzy zawarte są w Kodeksie Etyki Lekarskiej34.

Narracje z tej grupy wyraźnie zaznaczają, iż zawód lekarza nobilituje wywyższa, sytuuje na specjalnej pozycji. Ranga zawodu lekarza budowana była wraz z rozwojem medycyny. W XX w. lekarze, jak zauważa Jan Hartman ${ }^{35}$, osiągnęli wyżyny społecznego pre-

32 „Zawód lekarza należy do grona zawodów określanych mianem „zawodów z misją społeczną" wskazują B. Bajcar, A. Borkowska, A. Czerw, A. Gąsiorowska, Satysfakcja z pracy w zawodach $z$ misja społeczna. Psychologiczne uwarunkowania, GWP, Warszawa 2011, s. 17.

${ }_{33}$ Dz.U. z 2008 r. Nr 136, poz. 857; Dz.U. z 2009r. Nr 219, poz. 1708; Dz.U. z 1991r. Nr 91, poz. 408.

${ }^{34}$ B. Bajcar, A. Borkowska, A. Czerw, A. Gąsiorowska, op. cit., s. 18-19.

35 J. Hartman, Bioetyka dla lekarzy. Wydanie 2., LEX a Wolters Kluwer business, Warszawa 2012. 
stiżu. Istota etosu zawodu lekarza jest jednak niezmienna i nadal postrzegana jako służba wynikająca z powołania. Warto zaznaczyć, że obie idee - służba i powołanie - mają swoje źródła w chrześcijaństwie. Aczkolwiek służba lekarza nie jest tym samym co służba boża, należy ją postrzegać jako służbę ludzkości i konkretnemu człowiekowi w wymiarze ochrony jego życia i zdrowia.

[...] to sa osoby, które powinniśmy darzyć największym zaufaniem. A skoro ktoś obdarza mnie zaufaniem, to muszę temu sprostać. To nie jest tak, że dostaje to jako bonus ... Swoim dzieciom zawsze ttumacze, że ustawienie sie w takiej pozycji, obciaża nas dużo bardziej niż bycie jednym $z$ wielu w szeregu. Myśle, że to duża elita, która powinna świecić wzorem i przykładem (XIV/14/K).

Lekarz, to jeden z kilku zawodów, o których się mówi "profesja”. Czyli jest profesja medyczna i zrozumienie tego, jaka powinna być. Profesja [...], od łacińskiego stowa profession czyli przysięga. Jest kilka takich zawodów, które różnia się od innych tym, że ich członkowie zwiazani sa przysięga. [...] We krwi tego zawodu jest, że dobro pacjenta jest najważniejsze, że będę się chciat doskonalić, że będę chciat wspótpracować z kolegami lekarzami (VII/7/M).

I jeszcze bezinteresowność, że mu pomoge, chociaż mi nie zaptaca, bo jestem lekarzem. Jest nawet takie w kodeksie etyki lekarskiej zdanie, że jeżeli... Bo Hipokrates tym pisat. "Za swoja prace powinieneś otrzymywać godna płacę. Ale jeżeli staniesz wobec takiej sytuacji, że musisz komuś pomóc, a ktoś ci nie zaptaci, to musisz pomóc" (X/10/K).

Pozycję specjalną lekarz uzyskuje przez związanie przysięgą. Lekarz rozumiany jest tutaj jako profesjonalista. Pierwszy wymiar to kompetentny fachowiec obarczony odpowiedzialnością za zdrowie chorego. Drugi - to fachowiec stale się doskonalący, a trzeci wymiar nawiązuje do współpracy z kolegami. Lekarz swoją działalność opiera wiedzy i kunszcie. Posiadanie owego kunsztu i jego doskonalenie jest oczywistą częścią etosu. Aktualnie pojęcie kunsztu zostało rozszerzone i obejmuje umiejętności organizacyjne i społeczne związane ze współpracą w grupie, w określonej rzeczywistości. Mowa o działaniu rutynowo sprawnym, biegłym technicznie, o umiejętnym posługiwaniu się narzędziami w pracy, o działaniu 
z systemem opieki zdrowotnej. Działalność lekarza w aspekcie profesjonalizmu jawi się jako świadczenie usług, jednak jest to zredukowany punkt widzenia ${ }^{36}$.

Narratorzy mają świadomość powinności wobec chorych, którzy nie zawsze są lub będą w stanie uiścić opłatę za postawioną diagnozę i zaplanowany proces leczenia. Powyższe treści napawają optymizmem w aktualnej sytuacji, w której obraz zarówno służby zdrowia, jak i pracujących w niej osób nie jest optymistyczny. Potrafimy bez trudu wymienić nagłaśniane przez media nieudane interwencje medyczne, konflikty w relacjach lekarz - pacjent rujnujące zaufanie i wiarę w bezinteresowną pomoc.

\section{Codzienna}

Trzecia kategoria ujawnia realia wykonywanego zawodu jako tego, który nie ma norm czasowych i dotyczy głębokiego zaangażowania lekarza w problemy pacjentów. W tego rodzaju wypowiedziach najczęściej pojawia się określenie „zawód totalny". Narratorzy wskazują na obciążenie pracą i wiążące się $\mathrm{z}$ nią problemy (pacjentów). Oto ich przykłady:

Dla mnie to nie jest taki zawód, że się idzie do pracy „od-do" i się kończy. [...] Wtaściwie się nim żyje, zawsze wiedziałem, że tak jest (XVI/16/M).

Wracamy do domu złomotani czymś, co zaszło. Szpital widziany oczami lekarza jest pełen chorych, cierpiacych ludzi. Jeśli człowiek spędza tam mnóstwo czasu, to jakaśs część energii tam zostawia. [...] Nieraz rozmawiam z żona, która też jest czynnym lekarzem. Ona nosi w sobie pacjentów, co się przydarzyło, jakie byto nieszczęście. Lokata różnych emocji w to włożonych. To na pewno zmienia pogląd. Mówię studentom, że będac w medycynie zacznie inaczej zachowywać się w życiu. Jeśli musze podjać trudna decyzję, to odcinam medyk będę odcinat skrajne możliwości, wybierając to, co jest najbezpieczniejsze, bo taki jest sposób myślenia lekarza. [...] Na całe życie to się to przenosi. To zawód peten napięć (I/1/M).

36 B. Bajcar, A. Borkowska, A. Czerw, A. Gąsiorowska, op. cit. 
[...] Odbieram telefon może 40 razy dziennie, bo pacjenci dzwonia... Nie wiem czy to dobrze, ale po prostu tak to wyglada (IV/4/M).

Wczoraj wyszedtem z domu o 7.10, a wróciłem o 22.10, cały czas byłem w pracy. Byłem na oddziale. Byłem w szpitalu. Byłem w gabinecie, a później przyjechałem jeszcze zrobić wieczorna operację. Oczywiście, nie sam byłem na szczęście, ale z zespołem. Gdy wróciłem, dzieci już spaty [...] widzieliśmy się tylko rano pare minut przy śniadaniu (XIII/13/M).

[...] Do tej pory, jak mam ciężkiego chorego, to myślami jestem gdzie indziej. Tylko to już ma inny wyraz. To już musi być naprawdę ciężki pacjent. Na poczatku to wystarczyło, że byt lekko skomplikowany problem, a ja już głowe miałam ciagle zajęta $w$ tym chorym. Bardzo mi to życie uprzykrzało (X/10/K).

[...] to zawód wymagajacy, pilnowania się zawód, który nie wynika tylko ze złączenia literek, nie wynika tylko z tego, co doktor mówi, ale również z tego, jak się doktor zachowuje (VIII/8/K).

W narracjach tworzących kategorię codzienności ujawniany jest przede wszystkim wysiłek wkładany w pracę. Narratorzy koncentrują się przede wszystkim na zwykłych, powszednich czynnościach i podejmowanych wobec pacjentów działaniach. Ponadto bardzo wyraźnie odnoszą osobę lekarza do normalnego człowieka, który posiada określoną wydolność wysiłkową, odporność czy problemy. Co więcej, silnie podkreślają, że medyk w relacji lekarz pacjent, jest postawiony wobec zadania, któremu musi sprostać, będąc z jednej strony specjalistą, a z drugiej - człowiekiem rozumiejącym drugiego - pacjenta.

[...] normalni ludzie postawieni wobec konkretnych wyzwań (I/1/M).

Lekarz musi być przede wszystkim człowiekiem (VI/6/M).

[...] lekarz, który przede wszystkim ma dystans do siebie. Nie wywyższa się ponad innych. Jest dobrym człowiekiem. Ma odpowiedni charakter, żeby sobie radzić ze stresem (XII/12/M).

Rozumienie osoby lekarza i wykonywanego zawodu w prezentowanej kategorii, bardzo często pomija, podkreślaną w czasach wcześniejszych - wyjątkową pozycję, tj. autorytet, zdecydowanie 
większy szacunek i poważanie. Wybrani narratorzy zawód lekarza i zadania z nim związane sprowadzają do niełatwej, obarczonej odpowiedzialnością i obciążeniem pracy. Jednocześnie wskazują na różne relacje lekarz - pacjent, a zatem i te niepozbawione władzy i wiedzy.

\section{Wychowanie do zawodu}

Zaprezentowane znaczenia przypisywane profesji lekarza mają swoje implikacje dla praktyki nie tylko medycznej, ale również pedagogicznej. Chodzi tu przede wszystkim o wychowanie do zawodu przejawiające się uwrażliwianiem na potrzeby pacjenta, jego podmiotowość, autonomię i godność. Postrzeganie pełnionej roli zawodowej jako powołania i służby drugiemu człowiekowi wpływa na jakość podejmowanych czynności oraz na postrzeganie osób, wobec których dana czynność jest podejmowana. Z badań prowadzonych przez Neeli M. Bendapudi i jej zespół37 wynika, że „najlepszym” zachowaniem lekarza, o którym wspominali pacjenci była "dokładność", a najrzadziej - „empatyczność”. Z kolei „najgorszym doświadczeniem" był brak szacunku i wrażliwości ze strony lekarza. Autorzy badania wysnuli wniosek, że niska w ocenie pacjentów jakość opieki medycznej wynika z arogancji lekarza przejawiającej się odrzuceniem wkładu pacjenta $w$ leczenie, brakiem zainteresowania pacjentem jako osobą, brakiem cierpliwości w udzielaniu odpowiedzi pytania czy bezduszność przy omawianiu rokowania. Bez wątpienia wymiar stricte medyczny uprawianej profesji jest łatwiej realizować niż ten związany z kompetencjami miękkimi, np. komunikacją z pacjentem. Niemożliwa jest skuteczna pomoc pacjentowi bez uwzględnienia holistycznego spojrzenia na jego osobę - warunki życia, sytuację rodzinną czy przeżywane w związku z chorobą (choć nie tylko) emocje. Jako ludzie jesteśmy różni - $\mathrm{z}$ jednej strony - wyjątkowi i niepowta-

${ }^{37}$ M.N. Bendapudi, L.L. Berry, K. Frey, Turner, J. Parish, W.L. Rayburn, Patients' perspectives on ideal physician behaviors, "Mayo Clinic Proceedings" 2006, vol. 81, nr 7, s. 338-344. 
rzalni, a z drugiej trudni „do” relacji czy „ $\mathrm{w}^{\prime \prime}$ relacjach, bowiem konstytuowały nas różne doświadczenia ${ }^{38}$.

Edukacja i wychowanie lekarzy powinny być ukierunkowana na człowieka jako wyjątkową i niepowtarzalną osobę. Istotne jest zatem odniesienie w edukacji medycznej do kategorii antropologicznych ukształtowanych wewnątrz chrześcijaństwa, ułatwiających głębsze zaangażowanie osoby w obrany zawód/profesję, a zatem pomoc cierpiącemu. Lekarz musi chcieć i umieć kontaktować się z innymi ludźmi (pacjentami), jeśli chce dobrze wykonywać swoje obowiązki i stać na wysokości wypełnianych zadań. To, jak zachowujemy się wobec innych, decyduje o tym, że jesteśmy ludźmi. Co więcej, wspomniane kategorie wyraźnie uwypuklają istnienie duchowego wymiaru człowieka, który pozwala nawiązać osobową relację $\mathrm{z}$ pacjentem inicjującą proces wspierania chorego, towarzyszenia mu i bycia $\mathrm{z}$ nim, a zatem „wewnętrzne uzdrawianie" - o którym pisze Małgorzata Krajnik ${ }^{39}$.

W kształceniu do zawodu/profesji lekarskiej dobrze byłoby wprowadzić więcej godzin w ramach przedmiotów związanych z komunikacją czy tych, które kształtują kompetencje miękkie u przyszłych lekarzy ${ }^{40}$ (warto byłoby także weryfikować ich treści). W nauczanie niektórych przedmiotów czy zagadnień mogliby być włączeni pedagodzy specjalni. Wymaga zasygnalizowania fakt, że pedagogika specjalna, a zwłaszcza lecznicza ma wiele wspólnego z medycyną, np. zbieżny cel, którym jest naprawa tego, co zostało w organizmie człowieka uszkodzone lub zaburzone, pomimo że drogi do osiągnięcia owego celu są inne ${ }^{41}$, jednak wyraźnie kom-

${ }^{38}$ Zob. np. W. Eichelberger, I.A. Stanisławska, Być lekarzem być pacjentem. Rozmowy o psychologii relacji, Wydawnictwo Czarna Owca, Warszawa 2013.

${ }^{39}$ M. Krajnik, Whole-person care - hope for modern medicine? „Polish Archives of Internal Medicine" 2017, (on-line in press).

40 Wybiórcza analiza programów na uczelniach medycznych wskazuje na wciąż zbyt małą liczbę godzin przedmiotów związanych z komunikacją lub wiedzą i umiejętnościami pozamedycznymi.

${ }^{41}$ Zob. J. Doroszewska, Pedagogika specjalna, t. I, Zakład Narodowy im. Ossolińskich Wrocław, Warszawa, Kraków, Gdańsk 1981. 
plementarne. Pedagodzy specjalni czy leczniczy znając możliwości kompensacyjne ludzkiego organizmu i wagę akceptowania choroby czy niepełnosprawności $w$ funkcjonowaniu człowieka nim dotkniętego, posiadając wiele doświadczeń z pracy, z tą grupą pacjentów mogliby przekazywać wiedzę praktyczną (choć i także teoretyczną) oraz bardziej uwrażliwiać przyszłych lekarzy na problemy osób cierpiących.

Propozycją wartą rozważenia może być obligatoryjny kurs po ukończeniu studiów medycznych z zakresu komunikacji z pacjentem (analogicznie do kursu przygotowania pedagogicznego). Celem tegoż kursu byłoby wyposażenie przyszłych lekarzy w podstawowy warsztat umiejętności komunikacyjnych, poprzez dydaktyczne zastosowanie odpowiednich metod i technik nauczania (szkolenia) ${ }^{42}$.

Inną istotną kwestią, pomimo niezaprzeczalnej wartości wiedzy i umiejętności, które posiada zdecydowana większość lekarzy, jest ich pokora zarówno wobec siebie, jak i swoich osiągnięć. Pokora, dzięki której lekarz nieustannie zgłębia swoją wiedzę i umiejętności, a także traktuje siebie jak człowieka/bliźniego. „Lekarz nigdy nie będzie cudotwórcą. Bez względu na postępy nauki nigdy nie uda nam się stworzyć utopijnego świata, w którym dowolnie łatwo będzie wyleczyć każdą chorobę lub usunąć każdy strukturalny defekt organizmu. Byłoby więc dobrze, gdyby sztuce lekarskiej towarzyszyła pewna pokora płynąca ze zrozumienia niedoskonałości tej sztuki" - zaznacza Zbigniew Szawarski ${ }^{43}$.

\section{Bibliografia}

Antoszewska B., Ku człowiekowi. Doświadczanie relacji z pacjentem. Wybrane zagadnienia pedagogiki leczniczej, Oficyna Wydawnicza „Impuls”, Kraków 2018.

42 Zob. B. Antoszewska, Ku człowiekowi. Doświadczanie relacji z pacjentem. Wybrane zagadnienia pedagogiki leczniczej, Oficyna Wydawnicza „Impuls”, Kraków 2018.

${ }^{43}$ Z. Szawarski, Mądrość i sztuka leczenia, Obraz/Słowo/Terytoria, Gdańsk 2005, s. 352 . 
Bajcar B., Borkowska A., Czerw A., Gąsiorowska A., Satysfakcja z pracy w zawodach z misja społeczna. Psychologiczne uwarunkowania, GWP, Warszawa 2011.

Bendapudi M.N, Berry L.L., Frey K., Turner Parish J., Rayburn W.L., Patients' perspectives on ideal physician behaviors, "Mayo Clinic Proceedings" 2006, vol. 81, nr 7.

Berger P.L., Zaproszenie do socjologii, Wydawnictwo Naukowe PWN, Warszawa 1988.

Bogusz J., Lekarz i jego chorzy, PZWL, Warszawa 1984.

Brzeziński T., Wprowadzenie, [w:] Historia medycyny, red. T. Brzeziński, PZWL, Warszawa 2000.

Ceran W., Jan Chryzostom o leczeniu i lekarzach, "Acta Universitatis Lodziensis”. Folia Historica 1993, nr 48.

Chomczyński P., Paradygmat interpretatywny, [w:] Słownik socjologii jakościowe, red. K. Konecki, P. Chomczyński, Difin, Warszawa 2012.

Doroszewska J., Pedagogika specjalna, t. I, Zakład Narodowy im. Ossolińskich Wrocław, Warszawa, Kraków, Gdańsk 1981.

Eichelberger W., Stanisławska I.A., Być lekarzem być pacjentem. Rozmowy o psychologii relacji, Wydawnictwo Czarna Owca, Warszawa 2013.

Giddens A., Nowoczesność i tożsamość, Wydawnictwo Naukowe PWN, Warszawa 2012.

Grun A., Dufner M., Ta choroba zmierza ku życiu, Wydawnictwo Salwador, Kraków 2008.

Hartman J., Bioetyka dla lekarzy, Wydanie 2, LEX a Wolters Kluwer business, Warszawa 2012.

Historia medycyny, red. T. Brzeziński, Wydawnictwo PZWL, Warszawa 2000.

Hollender M.M.H., Stosunki między lekarzem i pacjentem, [w:] Psychologia w praktyce lekarskiej, red. M.H. Hollender, PZWL, Warszawa 1975.

Kępiński A., Poznanie chorego, Wydawnictwo Literackie, Kraków 2002.

Mała encyklopedia medycyny, red. P. Kostrzewski, J.Ziółkowski, Wydawnictwo Naukowe PWN, Warszawa 1999.

Orlicz-Benedycka M., Dehumanizacja medycyny zagraża lekarzom i pacjentom, „Medium" 12/2012-1/2015.

Pamiętniki lekarzy, red. K. Bidakowski, T.Wójcik, Wydawnicza Spółdzielnia czytelnik, Warszawa 1968.

Rozporządzenie Ministra Zdrowia z 2 stycznia 2013 w sprawie specjalizacji lekarzy i lekarzy dentystów (Dz.U. z 8 stycznia 2013 r., poz. 26).

Schwarz S., O zawodzie lekarza, „Przegląd lekarski” 1973, nr 5.

Sławecki B., Znaczenie paradygmatów w badaniach jakościowych, Badania jakościowe. Podejścia i teorie, red. D. Jemielniak, Wydawnictwo Naukowe PWN, Warszawa 2012.

Szawarski Z., Mądrość i sztuka leczenia, Obraz/Słowo/Terytoria, Gdańsk 2005.

Szewczyk K., Bioetyka. Medycyna na granicach życia, Wydawnictwo Naukowe PWN, Warszawa 2009. 
Szumowski W., Filozofia medycyny, Wydawnictwo Marek Derewiecki, Kęty 2005.

Thorwald J., Stulecie chirurgów, Wydawnictwo Znak, Kraków 2009.

Thorwald J., Triumf chirurgów, Wydawnictwo Znak, Kraków 2010.

Tokarczyk R., Normatywne aspekty relacji lekarz-pacjent, [w:] Humanizm i medycyna. Relacje lekarz-pacjent, red. K. Imieliński, Warszawa 1993.

Urbaniak-Zając D., Jakościowa orientacja w badaniach pedagogicznych, [w:] Badania jakościowe w pedagogice, red. D. Urbaniak-Zając, E. Kos, Wydawnictwo Naukowe PWN, Warszawa 2013.

Ustawa o zawodzie lekarza Dz.U. z 2011 nr 277 poz. 1634, Art. 2.2. 